\title{
The Review of Islamic Law on the Distribution of Zakat Directly by Muzaki to Mustahik in the Sunan Ampel Religious Tourism Area in Surabaya
}

\author{
Novi Febriyanti \\ Universitas Islam Negeri Sunan Ampel Surabaya \\ novikfbr@gmail.com
}

\begin{abstract}
BAZ/LAZ was formed as an implementation of zakat management objectives so that it runs well and professionally. Through this research, it can be seen how the implementation of zakat distribution in the Muslim community in carrying out zakat payments and the various factors that cause the Muslim community who is obliged to do zakat to choose to distribute zakat directly to mustahik. Related to this type of research, the researcher used descriptive qualitative research with sociological and empirical approaches. In this study, researchers took the research object in the Sunan Ampel Religious Tourism Area in Surabaya. From the results of this study it can be concluded that the pattern of zakat distribution in the Muslim community occurs in two policies, namely following the BAZ/LAZ policy and the policies pursued through the direct distribution of zakat. The factors causing direct distribution of zakat occur due to the lack of socialization of the latest laws, the long distance from BAZ/LAZ, lack of trust and muzakki feel that they are more affluent and practically pay zakat themselves. The emergence of these reasons, it can be said that the management of zakat is included in the distribution of zakat illegally and violates the law due to a lack of coordination in the management of zakat.
\end{abstract}

Keywords: Distribution of zakat, zakat directly, Muzaki, Mustahik

\section{INTRODUCTION}

Zakat is one of the pillars of Islam that must be carried out by Muslims who have met the requirements and pillars (Ibrahim, 2002). Of some of the assets, there are 8 asnaf rights and are a deposit from Allah SWT in capable people (BAZNAS, 2020). Zakat is an obligation for every Muslim that has been established by Allah SWT through His Word (Muhyiddin, 2003). Zakat is one of the pillars of Islam which is always said to be parallel to prayer. This shows that zakat is important for all Muslims. The importance of being obliged to pay zakat is mainly because this commandment contains a social mission which has very clear objectives for the benefit of mankind, aimed at solving the problem of poverty and improving the welfare of the people (Muhammad, 2019). Apart from being closely related to the aspects of divinity, social and economic mission, among the aspects of divinity (transcendental) are the many verses of the Qur'an that mention the problem of zakat. Even the Prophet also placed zakat as one of the main pillars in upholding Islam. Meanwhile, from the social mission (al'adalah al-ijtima'iyah), the 
command of zakat can be understood as an inseparable unit in economic empowerment in order to achieve social and social welfare (Nuruddin, 2006).

The law of issuing zakat is obligatory (fardhu), that is, it is obligatory on every Muslim who has fulfilled the requirements determined by a set of rules based on the provisions of Allah SWT (syara'). Islam pays great attention to the issue of zakat. It is proven by the existence of Allah's commandment regarding zakat in the Qur'an as many as 32 verses and 28 times the commandment that goes hand in hand with the commandment of prayer, coupled with the mention of the word zakat which uses the terms shadaqah and infaq. So the overall existence of the order states as many as 58 verses containing 26 letters (Abdul, 2002). Islamic economic thinkers define zakat as assets that have been determined by the government or authorized officials to the general public or individuals that are binding, without receiving certain rewards, zakat is allocated to meet the needs of the eight groups specified in the Qur'an and fulfill the demands of Islamic finance politics (Mahmud, 2006). In another perspective, it is the presence of the state and more precisely the government because it regulates public relations. The government's role is very strategic in encouraging the success of zakat management laws in Indonesia (Gazi, 2003).

In an effort to achieve success in the law of zakat management in accordance with the Law of the Republic of Indonesia No. 23 of 2011, previously there was a law regulating zakat management, namely Law of the Republic of Indonesia No. 38 of 1999. The drafting of this new law was none other than to improve the previous law. In this way, the National Zakat Agency (BAZNAS) was formed, which is domiciled in the State Capital, Province and City. BAZNAS is an institution that has the authority to carry out the task of managing zakat nationally (UU RI, 2011). The new law no longer uses the generic name "Badan Amil Zakat" for governmentinitiated institutions, as used in the previous law. However, the new law expressly stipulates BAZNAS (National Zakat Agency) as the authorized institution in managing zakat. Meanwhile, other private institutions that are not acquired by the government are even subject to sanctions if they continue to act as amil zakat institutions or Islamic bodies in managing zakat.

In discussing the management and utilization of zakat, there are several things that are known, namely the timing of zakat payments by muzaki, the payment to the groups entitled to receive it, the method of payment, distribution and managing institution. The New Law No. 23 of 2011 regarding zakat management is clearly intended to ensure order and accountability in planning the collection, distribution and utilization of zakat as well as reporting and responsibility for the implementation of zakat management (Ana Toni, 2016). This recently amended law does not satisfy how amil zakat must be listed and what is legal in Indonesia that is allowed to become 
Febriyanti. The Review of Islamic Law on the Distribution of Zakat

amil zakat. In fact, people who have trusted and been elected directly by their citizens cannot carry out their duties as amil zakat. In the law it is very clear that the role of zakat management is taken over by BAZNAS. This invites controversy from various circles, especially local residents who have been trusted as traditional amil zakat, such as in mosques or prayer rooms, foundations or villages, even directly, which is usually done by muzaki to mustahik.

Routines that are usually carried out by muzaki in distributing zakat directly to mustahik have emerged because it seems that the management of zakat itself is not optimal by the government. This can also occur because the public does not really realize that the zakat paid will be able to alleviate their situation, encourage social mobility, minimize inequality and even improve the national economy (Amiruddin, 2015). The existence of a crisis of public confidence in the performance of the Government is one of the reasons why there are many controversies in the management of zakat that are directly handled by the government, because it is feared that there will be opportunities for corruption and inequality in the distribution of zakat (Indah, 2015). BAZNAS in East Java has the potential for promising zakat management with the support of the large number of Muslim communities in East Java, amounting to $94.61 \%$ of all religions (BPS, 2020). In 2019 the target of collecting zakat, infaq and shodaqah (ZIS) for BAZNAS East Java will increase to 9 trillion. SiMBA data until November 18 last year showed the collection of ZIS BAZNAS East Java was still at 65.955 billion. This means that East Java BAZNAS contribution is still very small, only $0.73 \%$ (Salam, 2020).

These figures reflect two interrelated realities. First, in general the performance of the East Java BAZNAS ZIS collection was not optimal. Second, in the East Java region there are still many muzaki who give zakat or pay zakat to illegal amil or directly to mustahik and not through BAZNAS East Java. The second reality that can be minimized will certainly have a positive effect on increasing the results of the ZIS BAZNAS East Java fundraising. One area in East Java where the people are dominant in paying zakat directly to mustahik is in the SemampirSurabaya sub-district, the Sunan Ampel Religious Tourism Area (Madyan, 2015). When the writer interviewed one of the people, he said that there are still some muzaki in the Sunan Ampel Religious Tourism Area in Surabaya who distribute their zakat directly. According to the author's observer, there are many factors behind the muzaki paying zakat directly to mustahik, although there are KUA, Ustadz, mosques and religious figures, but all of them have not been able to take over the function of the amil zakat institution. So that muzaki still pay zakat directly to mustahik, one of the factors behind this is the distance that is so far from the location of BAZNAS in East Java. Furthermore, the lack of trust of muzaki in amil zakat institutions so that muzaki pay zakat directly to mustahik (Irfan, 2013). 
The level of direct distribution of zakat by muzaki to mustahik in the Sunan Ampel Religious Tourism Area in Surabaya is interesting to study with the formulation of the problem to find out how the application of zakat distribution to the surrounding Muslim community as mandatory zakat in the Sunan Ampel Religious Tourism Area in Surabaya, as well as the factors that cause the Muslim community zakat obligatory chooses to distribute zakat directly to mustahik. The benefits of this research can provide clarity on how to implement Law No. 23 of 2011 concerning zakat management, knowing the factors that cause the Muslim community to be obliged to do zakat, which distributes their zakat directly to mustahik. In addition, to enrich insight and knowledge, especially those related to the latest zakat management laws.

\section{LITERATURE REVIEW}

\section{A. ZAKAT}

\section{Definition of Zakat}

Zakat according to language means blessing, clean and developing. It is called a blessing, because by paying zakat, his wealth will increase or not decrease, so that his wealth will grow because of the gifts and blessings given by Allah SWT to a muzaki (Hikmat, 2008). Zakat according to the term is a number of certain assets that are required by Allah SWT to be given to people who are entitled (8 asnaf namely needy, poor, amil, converts, al riqab, gharimin, fii sabilillah, ibnu sabil) (Al-Furqan, 2008). There are several opinions of the Mazhabs regarding the meaning of zakat, including the Maliki Mazhab of defining, "zakat is the issuing of a special part of the special assets that have reached the nishab (quantity limit) to those who are entitled to receive it." The Hanafi Mazhab defines, "zakat is to make part of the special assets of the special assets belong to a special person as determined by the Shari'a because of Allah SWT." Mazhab of Shafi'i, "zakat is a money when it comes out of wealth or grows according to a special way." Meanwhile, according to the Hambali Mazhab, "zakat is a right that must be issued from a special property for a special group as well” (Wahbah, 1997).

Meanwhile, according to the general provisions in Article 1 of Law No. 23 of 2011 concerning Zakat Management, zakat is an activity of planning, implementing and coordinating the collection, distribution and utilization of zakat. The management of zakat in Indonesia must be based on Islamic law which is mandatory, usefulness, justice, legal certainty, integrated and accountability (UU RI, 2011). The management of zakat also aims to increase the effectiveness and efficiency of services in managing zakat and increase the benefits of zakat to create social welfare. Islam demands that someone who is capable (rich) help and assist the poor (poor) in covering their life expenses and also carry out the interests of life in general. Zakat is obligatory 
for people who can afford it, their wealth is more than their own interests and the interests of those who are unable to become dependents (Uud, 2018). According to IAI (2008) in PSAK No. 109 , zakat is an asset that must be issued by muzaki in accordance with sharia provisions to be given to those entitled to receive it (mustahik) (Dwi, 2012).

\section{Legal Baziz of Zakat}

The practice of managing zakat can be understood implicitly from the word of Allah SWT in Surah At-Taubah verse 103 (Departemen Agama RI, 2016),

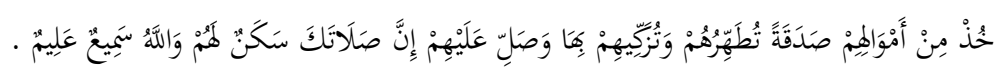

"Take zakat from part of their property, to clean and purify them and pray for them. Indeed, your prayer (brings) peace of mind for them. Allah is All-Hearing, All-Knowing."

Apart from that, Rasulullah saw. also gave a message to Muadz bin Jabal's friend when he was about to be sent to Yaman to spread Islam there. Before leaving the Prophet Muhammad said (NU, 2020),

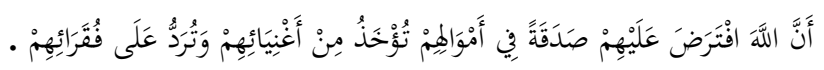

"Indeed, Allah SWT has obliged zakat on their property, which is taken from the rich among them and distributed to those in need," (Bukhari and Muslim).

\section{Terms and Pillars of Zakat}

In the system of implementing zakat, there are several requirements for zakat for muzaki (compulsory zakat), namely Islam, freedom, intelligence, perfect assets and achieving nishab (Wahbah, 1985). The conditions for zakat muzaki are as follows (Mu'inan, 2011):

a. Al-Milk at-tam is property owned by someone who is legally controlled, obtained from lawful business, including work, inheritance and gifts.

b. An-Nama 'is a property that develops if it is cultivated, such as any plant that produces and is useful for paying zakat.

c. Having reached the nishab, it means that the assets owned or managed have reached the minimum limit of assets required to pay zakat.

d. Having reached al-ashliyyah (basic needs), meaning that he has reached the minimum needs needed by the family for his survival.

e. Having reached al-Haul, meaning that the assets have reached at least one year of Qamariyah (money and merchandise). 
While the requirements for the mustahik who are entitled to receive zakat are as follows (BAZNAS, 2020):

a. Needy, those who have almost nothing so they are unable to meet the basic needs of life.

b. Poor, those who have property but not enough to meet basic needs for life.

c. Amil, those who collect and distribute zakat.

d. Muallaf, those who have just converted to Islam and need help to strengthen in monotheism and sharia.

e. Al riqab, slaves who want to free themselves.

f. Gharimin, those who are in debt for the necessities of life in maintaining their soul and izzah.

g. Fii sabilillah, those who struggle in the way of Allah in the form of da'wah activities, jihad and so on.

h. Ibn Sabil, those who run out of expenses on the way in obedience to Allah.

Meanwhile, for the harmonious zakat are elements that must be fulfilled before implementing zakat, namely (Syaikh, 2000):
a. People who give zakat (muzaki).
b. Assets paid zakat.
c. People who are entitled to receive zakat (mustahik).
d. Amil takes care of zakat.

\section{B. THE LAW NO 23 OF 2011 CONCERNING ZAKAT MANAGEMENT}

In the law what is meant by zakat management is the activity of planning, implementing and coordinating the collection, distribution and utilization of zakat. The performance of amil zakat in its role, namely as a collector and distributor of zakat funds that have been collected to mustahik. It is confirmed later in the law that BAZNAS (National Zakat Agency) is an institution that has the right to manage zakat in Muslim communities in Indonesia. In the Law No 23 of 2011 concerning Zakat Management,

Article 38: "Everyone is prohibited from deliberately acting as amil zakat by collecting, distributing or utilizing zakat without permission from the authorized official".

Article 41: "Every person who deliberately and violates the law violates the provisions referred to in Article 38 shall be sentenced to a maximum imprisonment of 1 (one) year and/or a maximum fine of 50,000,000 (fifty million rupiahs)". 
Febriyanti. The Review of Islamic Law on the Distribution of Zakat

Although the Republic of Indonesia is a National State, paying attention to the development goals of the Indonesian State is identical to the targets and objectives of zakat. As has been explained that amil zakat can be interpreted as BAZ/LAZ, the functions and duties of $\mathrm{BAZ/LAZ} \mathrm{are} \mathrm{as} \mathrm{the} \mathrm{national} \mathrm{zakat} \mathrm{manager.} \mathrm{The} \mathrm{management} \mathrm{of} \mathrm{zakat} \mathrm{is} \mathrm{aimed} \mathrm{at} \mathrm{increasing}$ the effectiveness and efficiency of services in managing zakat and increasing the benefits of zakat to create community welfare and poverty alleviation.

\section{METHODOLOGY}

This research method uses descriptive qualitative with sociological and empirical approaches. The definition of empirical research is to reveal the implementation of the law that lives in society through social activities carried out by the community by looking at a legal reality in society (Bambang, 1997). In this research, the writer focuses on the results of data collection obtained directly from the informants and sources who have been determined (Sugiyono, 2019). The research was carried out by going directly to the field to see the symptoms and events that occurred as well as related to the management and development and distribution of zakat in the Sunan Ampel Religious Tourism Area in Surabaya. For data analysis is descriptive, because this research describes and describes objectively the things related to Islamic law to the distribution of zakat directly by Muzaki to Mustahik in The Sunan Ampel Religious Tourism Area in Surabaya.

\section{RESULT AND DISCUSSION}

The application of zakat distribution to the Muslim community as mandatory zakat in the Sunan Ampel Religious Tourism Area in Surabaya

Islam is a religion that is blessed by Allah SWT, this is in line with the word of Allah SWT in Surah Al Imran verse 19. Islam is a religion whose teachings were revealed by Allah SW'T to the Muslim community through the Prophet Muhammad saw. Islam in essence carries teachings that are not only about one aspect of life, but various aspects of human life. The source of the teachings of Islam comes from the Qur'an and Hadith. Islam has rukun as a basic act, it is also considered as an obligatory foundation for those who believe and is the basis for Muslims. The pillars of Islam have five things, namely (Nurcholish, 1992):

1. Say two sentences of the creed

2. Establish prayers

3. Fasting during the month of Ramadan

4. Paying zakat 


\section{Perform Hajj for those who can afford it}

Islam is a universal religion that regulates all aspects of life, both regarding the relationship with Allah SWT or the relationship between fellow humans. Hablum minallah can be reached by carrying out worship activities, praying and fasting as a means of getting closer to the khaliq. Hablum minannas can be reached by paying attention to the people around you by providing assistance to those in need in the form of zakat, infaq, and shadaqah (Muhammad, 2013). Zakat is a certain right required by Allah SWT for Muslims to reach out to those that are intended for them, who are mentioned in the Qur'an as among the poor and other mustahics. Because of the importance of zakat in social functions, the Koran obliges all Muslims to pay zakat from everything that comes out of the land. As Allah SWT says in surah al-Baqarah verse 267.

Zakat is very important for the life of the nation and state, in the aim of a state of course there is a mission to prosper the people, and zakat is one of the right ways. In the zakat management system, zakat is taken from rich people and given to poor people, including the 8 asnaf that have been stipulated in Surah at-Taubah verse 60, namely needy, poor, amil, muallaf, al riqab, gharimin, fii sabilillah and ibn sabil. Among the eight asnaf, there are poor and poor, these two parts are problems that must be resolved by the government. The existence of zakat really helps the government to overcome this problem. This is often experienced in Semampir District, Surabaya City. Semampir District occupies the majority of the Muslim community in the Sunan Ampel Religious Tourism Area in Surabaya (Chotib, 2020).

The pattern of payment and distribution of zakat for the Muslim community in the Sunan Ampel Religious Tourism Area in Surabaya is carried out in two ways, namely through the Amil Zakat Institution and directly meeting the mustahik. There are generally 2 (two) types of zakat collection system by the Amil Zakat Institution, namely (Sahal, 2020):

1. Pick up system

Here, BAZ/LAZ is used to visiting muzaki's house who will pay zakat, for muzaki who cannot come to the BAZ/LAZ office then asks BAZ/LAZ to pick up their zakat. Then BAZ/LAZ will pick up zakat muzaki according to the request. So not only waiting for the muzaki to come to pay zakat, but also to pick up or take the zakat funds from the muzaki's house.

2. Deposited

In the deposit option, you can go through the collection field or through the BAZ/LAZ account. Muzaki can come directly to the nearest BAZ/LAZ to pay zakat through the collection of zakat and muzaki can also deposit zakat through a zakat account 
that has been determined by BAZ/LAZ. The use of zakat accounts is for muzaki who want to pay their zakat but do not have time or do not have time to come to BAZ/LAZ, then muzaki can come directly to the bank or through m-banking that has been appointed by BAZ/LAZ to make transactions.

Meanwhile, direct payment and distribution of zakat made by muzaki is limited to receiving zakat funds directly from local residents who trust the committee as the local zakat management unit to manage the zakat, and its management is only around the Sunan Ampel Religious Tourism Area in Surabaya. The form of reporting to the community, the local zakat management unit reports in the form of a bulletin board in every village. The zakat funds received are given directly to the local mustahik because of the data related to group 8 asnaf of the closest community (Zein, 2020). The distribution of zakat directly is mostly carried out by the surrounding community to amillins in mosques or prayer rooms and also the local zakat management unit. Although there are some people who pay their zakat directly, they meet people who they think that they are entitled to zakat. This appeal is in line with the trend in the community in every month of Ramadan where there is still direct distribution of zakat by collecting large amounts of zakat recipients. Thousands of poor people are willing to queue and jostle to get zakat funds. Even some elderly people and children must be ready to be crushed in the middle of the crowd of zakat recipients. There are also those who pay zakat through the three. This is because several factors are related to the goal, namely the feeling of helping can be realized more quickly and compassion for the less fortunate people in the environment around the place of residence (Angga, 2020).

\section{The factors that cause the Muslim community zakat obligatory or muzaki chooses to distribute zakat directly to mustahik}

So many applications of direct distribution of zakat in the Religious Tourism Area of Sunan Ampel Surabaya have an impact on the target of amil zakat institutions, especially BAZNAS East Java in collecting and distributing zakat funds for the Muslim community who are obliged to zakat. This is because there are factors that cause these problems to occur, including the following,

1. Lack of socialization on the application of Law No. 23 of 2011

Lack of socialization, which has an impact on the activities of collecting and distributing zakat. It is undeniable that to attract the interest of muzaki in distributing zakat through the amil zakat institution, especially BAZNAS East Java, it must hold more optimal socialization, such as the purpose of the socialization, namely, conveying information about zakat and BAZ/LAZ to the public, after the information arrives and 
the community understands it is expected the community will carry out the message in the socialization, of course raising awareness of zakat payments through BAZ/LAZ which have been acquired by the government (Leilila, 2020).

2. Long distance to BAZ/LAZ location

Long distances are also an obstacle for muzaki to pay zakat to amil zakat institutions, especially BAZNAS East Java, so that muzaki pay their zakat at amilins of mosques or prayer rooms and also local zakat management units. As stated that on the other hand the muzaki pay their zakat by giving it to the mustahik directly (Angga, 2020).

3. Lack of muzaki trust in amil zakat institutions

There is a lack of trust in the Muslim community or muzaki as compulsory zakat to pay zakat to BAZ/LAZ, in this case there are muzaki who are afraid that the zakat money will be misused and are afraid that the zakat funds will not be distributed to people who really need it. Then there are muzaki who say that their zakat is right on target and not misused (Chotib, 2020).

4. Feel more comfortable giving zakat directly to mustahik

Muzaki feels that it is more affordable and practical to pay his own zakat, then they can choose whoever the mustahik they will give zakat. This reason means that people who are obliged to zakat know better about the less fortunate people in the surrounding environment and can help directly by giving more freedom directly to those who belong to the closest group of 8 asnaf (Nawawi, 2020).

The Review of Islamic Law on the Distribution of Zakat Directly by Muzaki to Mustahik in the Sunan Ampel Religious Tourism Area in Surabaya

Prior to the emergence of Law No 23 of 2011 on Zakat Management, there is Law No 38 of 1999. This latest law has given birth to a new paradigm, among other things, giving the understanding to the Muslim community that a new forum is born to handle the management empowerment of zakat, namely the National Amil Zakat Board established by the government. These agencies consist of elements of the community and government as well as the Amil Zakat Institution which is fully formed by and from the community. Furthermore, the change of the new law, namely Law No 23 of 2011 is meant by zakat management, which is the planning, implementation and coordination of the collection, distribution and utilization of zakat. It is confirmed later in the law that BAZNAS is an institution that has the right to manage zakat nationally. BAZNAS's performance as an amil zakat group is as an officer who collects and distributes zakat funds that have been collected to mustahik. 
Febriyanti. The Review of Islamic Law on the Distribution of Zakat

As the legal policy that has been explained regarding the zakat management law, the collectors of zakat or amil are a person or group of people appointed by the government to carry out the task of managing zakat. A person or group of people can be declared to have been authorized by the government to manage zakat. Thus, they are the ones who collect and distribute zakat funds from muzaki to mustahik. Of course, these officers are selected from those who are known to be honest and trustworthy, have the ability to manage and carry out their duties with high transparency and responsibility.

The distribution pattern in the payment of zakat for the Muslim community in Semampir-Surabaya District itself, precisely in the Sunan Ampel Religious Tourism Area, Surabaya, is carried out in two ways, namely through the Amil Zakat Institution and directly meeting the mustahik. There are generally 2 (two) types of zakat collection system by the Amil Zakat Institution, namely the system of being picked up and deposited. The pick-up system means that BAZ/LAZ is accustomed to visiting the muzaki's house who will pay zakat, for those muzaki who cannot come to the BAZ/LAZ office then ask BAZ/LAZ to pick up their zakat. Then BAZ/LAZ will pick up zakat muzaki according to the request. So not only waiting for the muzaki to come to pay zakat, but also to pick up or take the zakat funds from the muzaki's house.

In the deposit option, you can go through the collection field or through the BAZ/LAZ account. Muzaki can come directly to the nearest BAZ/LAZ to pay zakat through the collection of zakat and muzaki can also deposit zakat through a zakat account that has been determined by BAZ/LAZ. The use of zakat accounts is for muzaki who want to pay their zakat but do not have time or do not have time to come to BAZ/LAZ, then muzaki can come directly to the bank or through m-banking that has been appointed by BAZ/LAZ to make transactions. Meanwhile, the direct payment and distribution of zakat made by muzaki is limited to receiving zakat funds directly from local residents who trust the committee as the local zakat management unit to manage the zakat, and its management is only around the Sunan Ampel Surabaya area. The form of reporting to the community, the local zakat management unit reports in the form of a bulletin board in every village. The zakat funds received are given directly to the local mustahik because of the data related to the group of 8 asnaf of the closest community. Direct zakat payments are made by the local community to amillins in mosques or prayer rooms and also the local zakat management unit. Although there are some people who pay their zakat directly to people who they think that they are entitled to zakat.

This appeal is in line with the trend in the community in every month of Ramadan where there is still direct distribution of zakat by collecting large amounts of zakat recipients. 
Thousands of poor people are willing to queue and jostle to get zakat funds. Even some elderly people and children must be ready to be crushed in the middle of the crowd of zakat recipients. There are also those who pay zakat through the three. This is because several factors are related to the goal, namely the feeling of helping can be realized more quickly and compassion for the less fortunate people in the environment around the place of residence. With so many applications of direct zakat payments in the Sunan Ampel area of Surabaya, it has an impact on the target of amil zakat institutions, especially BAZNAS East Java in collecting and managing zakat funds for the Muslim community who are obliged to zakat. This is because there are factors that cause these problems to occur, including the following,

First, the lack of socialization, which has an impact on the activities of collecting and distributing zakat. It is undeniable that to attract the interest of muzaki in distributing zakat through the amil zakat institution, especially BAZNAS East Java, it must hold more optimal socialization, such as the purpose of the socialization, namely, conveying information about zakat and BAZ/LAZ to the public, after the information arrives and the community understands it is expected the community will carry out the message in the socialization, of course raising awareness of zakat payments through BAZ/LAZ which have been acquired by the government.

Second, long distances are also an obstacle for muzaki to pay zakat to amil zakat institutions, especially BAZNAS East Java, so that muzaki pay zakat in Amilin at mosques or prayer rooms and also the local zakat management unit. As stated that on the other hand the muzaki pay their zakat by giving it to the mustahik directly. Third, there is a lack of trust in the Muslim community or muzaki as compulsory zakat to pay zakat to BAZ/LAZ, in this case there are muzaki who are afraid that the zakat money is misused and are afraid that the zakat funds will not be distributed to people who really need it. Then some muzaki say that their zakat is right on target and not misused. Fourth, muzaki feel it is more affordable and practical to pay their own zakat, then they can choose which mustahik they will give their zakat to. This reason means that people who are obliged to zakat know better about the less fortunate people in the surrounding environment and can help directly by giving more freedom directly to those who belong to the closest group of 8 asnaf.

Based on these reasons, it can be stated that the distribution of zakat is included in the distribution of zakat illegally and violates the law because it is not through an agency that has been acquired by the government. He has no right and no obligation in handling this matter, by allowing by accepting and letting the property owners settle the matter of giving (distributing) zakat. This has an impact on the amil zakat institution, especially BAZNAS East Java due to a decrease in the receipt of zakat funds. The main thing that is the reluctance of the people to be 
Febriyanti. The Review of Islamic Law on the Distribution of Zakat

obliged to pay zakat to pay their zakat to the amil zakat institution, especially BAZNAS East Java, is due to the lack of trust of muzaki to pay their zakat through the amil zakat institution, especially BAZNAS East Java. Then followed by public opinion which makes this reason that people are obliged to do zakat or muzaki in which they feel there is a special satisfaction when they themselves pay their zakat directly to the mustahik.

The effectiveness of the law in theory has become a legal postulate that the functioning of a law is a sign that the law can achieve legal objectives. The purpose of zakat management law was created to maintain and protect people in social life. In terms of unequal economic life, the community needs strong and careful empowerment through the applied laws and policies. In order for law to function in society, it really has to fulfill three elements of the law of life, namely to apply juridically, sociologically and philosophically.

\section{CONCLUSION}

Description and analysis shows that the distribution pattern in the payment of zakat occurs in two policies. The first policy follows the provisions of the amil zakat institution, especially BAZNAS East Java and the second policy takes the direct payment of zakat. The first policy contains two systems/methods, namely picked up and deposited. The second policy is the payment of zakat through Amilin at the mosque and also the local zakat management unit and the payment of zakat made directly by muzaki to the mustahik he chooses. The factors causing the direct payment of zakat are due to the lack of socialization of the latest law, the long distance from BAZNAS/LAZ, the lack of trustworthiness and the muzaki feel that it is more affordable and practical to pay their own zakat. The emergence of these reasons, it can be stated that the direct distribution of zakat enters into the distribution of zakat illegally and violates the law. Because, often if an amil institution does not have a permit, the zakat collection and distribution movements will run independently. The need for socialization and education on statutory regulations in providing guidance on legality aspects that must be fulfilled by each amil zakat institution. Therefore, it is hoped that all zakat institutions can fulfill this legality aspect. In principle, the existing regulations aim to make zakat management more coordinated.

\section{REFERENCES}

Ali, Nuruddin. 2006. Zakat sebagai Instrumen dalam Kebijakan Fiskal. Jakarta: PT. RajaGrafindo Persada.

Amir, Muhammad Fakhri. 2019. Faktor Deminan Tingkat Pendapatan Mustahiq Penerima Zakat Produktif. Iqtishaduna. Vol. 10, No. 2. 151-160. 
Ayyub, Syaikh Hasan. 2000. Fikih Ibadah. Jakarta: Pustaka al-Kautsar.

Bajuri (al), Ibrahim. 2002. Hasyiyah al-Bajuri 'ala Syarb Ibnu Qasim al-Ubaidi. Beirut: Dar al-Fikr.

Chotib, Muhammad. 2020. Chairman of the Ampel Religious Tourism Area Tourism Awareness Group. Interview. Surabaya, Sept 08, 2020.

Departemen Agama RI. 2016. Al-Quran Special for Muslimah. Jakarta: Cordoba.

Hasbi, Al-Furqan. 2008. Masalah Zakat. Solo: PT Tiga Serangkai Pustaka Mandiri. 2008.

Hismi, Angga Dian. 2020. Traders and Chairman of the Small Traders Association. Interview. Surabaya, Sept 10, 2020.

Inayah, Gazi. 2003. Teori Komprehensif tentang Zakat. Yogyakarta: Tiara Wacana.

K, Amiruddin. 2015. Model-model Pengelolaan Zakat di Dunia Muslim. Abkam. Vol. 3, No. 1. Juli. 139-166.

Kurnia, Hikmat. 2008. Panduan Pintar Zakat. Cet. I, 2. Jakarta: Qultum Media.

Madjid, Nurcholish. 1992. Islam dan Peradaban. Jakarta: Yayasan Waqaf Paramadina.

Madyan M. 2015. Dampak Ekonomi Wisata Religi, Studi Kasus Kawasan Wisata Sunan Ampel Surabaya. Jurnal BISMA. Vol. 7, No. 2. 101-106.

Mahmud, Abdul al-Hamid. 2006. Ekonomi Zakat Sebuah Kajian Moneter dan Keuangan Syariah. Jakarta: PT RajaGrafindo Persada.

Muhaimin, Abdul Wahab dan Abdul. 2002. Hukum Pranata Sosial. Abkam. Vol. 9, No. 4. 13-32.

Nawawi (an), Muhyiddin. 2003. al-Majmu’ Syah al Muhadzdzab. Mesir: al-Muniriyah.

Nawawi, Abd. Salam. 2020. Chairman of BAZNAS Jawa Timur. Interview. Sept 04, 2020.

Nawawi, Ahmad Hifni. 2020. Directur of LPBA Sunan Ampel. Interview. Surabaya, Sept 17, 2020.

NU Online. 2020. Konsep Dasar Zakat dan Hartanya. Retrieved from https://islam.nu.or.id/post/read/115916/konsep-dasar-zakat-dan-ketentuan-hartanya.

Nurhafida, Leilila Aini. 2020. ASN. Interview. Surabaya, Sept 14, 2020.

Pratama C., Beik dan Irfan Syauqi. 2016. Analisis Pengarub Zakat Terhadap Penurunan Tingkat Kemiskinan dan Peningkatan Kesejabteraan Mustabik Berdasarkan Model CIBEST, on Irfan Syauqi Beik dan Laily Dwi Arsyianti. Ekonomi Pembangunan Syariah. Edisi 1 Cetakan 1. Jakarta: Rajawali Press.

Purbasari, Indah. 2015. Pengelolaan Zakat oleh Badan dan Lembaga Amil Zakat di Surabaya dan Gresik. Mimbar Hukum. Vol. 27 No. 1. Februari. 68-81.

Rafi', Mu’inan. 2011. Potensi Zakat: Perspektif Hukum Islam. Yogyakarta: Citra Pustaka.

Sahal, KH. Ahmad Sholeh. 2020. Lecturer at Ampel Suci College of Arabic Language and Da'wah. Interview. Surabaya, Sept 08, 2020.

Soenggono, Bambang. 1997. Metodologi Penelitian Hukum. Jakarta: PT RajaGrafindo Persada. 
Febriyanti. The Review of Islamic Law on the Distribution of Zakat

Sugiyono. 2019. Metode Penelitian Kuantitatif, Kualitatif dan R\&DD. Bandung: Alfabeta.

Tanujaya, Dwi Martani, et. al. 2012. Akuntansi Keuangan Menengah Berbasis PS AK. Jakarta: Salemba Empat.

The Central Statistics Agency (BPS). 2020. Penduduk Menurut Agama yang Dianut (Jiwa). Retrieved from https://rembangkab.bps.go.id/indicator/108/209/1/penduduk-menurut-agamayang-dianut.html.

The Law of the Republic of Indonesia (UU RI) No. 23 of 2011 about Zakat Management.

The Law of the Republic of Indonesia (UU RI) No. 38 of 1999 about Zakat Management.

The National Zakat Agency (BAZNAS). 2020. 8 Asnaf yang Menerima Manfaat Zakat. Retrieved from https://baznas.go.id/asnaf.

Wahyudin, Uud. 2018. Sosialisasi Zakat Untuk Menciptakan Kesadaran Berzakat Umat Islam. Jurnal Masyarakat Dan Filantropi Islam. Vol. 1, No. 1, November. 17-20.

Wildana, Muhammad Dandy Alif., Manzilati, Asfi. (2013). Hablum minallah dan Hablum minannas dari Zakah, Jurnal Ilmiah Mahasiswa FEB Universitas Brawijaya. Vol. 2 No. 2. 47.

Yudha, Ana Toni Roby Candra. 2016. Manajemen Pelayanan Pemberdayaan Anak Yatim pada Lembaga Amil Zakat Yatim Mandiri di Surabaya. Al-Tijarah. Vol. 2, No. 1. 1-30.

Yusuf, Zeid Muhammad. 2020. Takmir MASA in the field of worship. Interview. Surabaya, Sept 10, 2020.

Zuhaili (az), Wahbah. 1985. Figh Islam Wa Adillatubu. Jakarta: Gema Insani. 1997. Zakat Kajian Berbagai Mą̧ab. Bandung: PT Remaja Rosdakarya. 